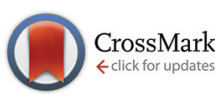

Cite this: Org. Biomol. Chem., 2015, 13, 10496

\section{Synthesis and investigation of singlet oxygen production efficiency of photosensitizers based on meso-phenyl-2,5-thienylene linked porphyrin oligomers and polymers $\uparrow$}

\author{
Rehan Khan, $t^{a}$ Muazzam Idrisț and Dönüs Tuncel*a,b \\ Three new Zn(॥)-, oligo- and poly(2,5-thienylene)-linked porphyrins, bearing multiple triethylene glycol \\ (TEG) groups, on all meso aryl positions were synthesized via Stille and Suzuki coupling reactions and \\ their photophysical properties as well as singlet oxygen generation efficiencies have been investigated to \\ elucidate the possibility of their use as a photosensitizer for photodynamic therapy (PDT) and photo- \\ dynamic inactivation of bacteria.
}

Received 14th July 2015,

Accepted 24th August 2015

DOI: $10.1039 / c 5 o b 01435 b$

www.rsc.org/obc

\section{Introduction}

Efficient photosensitizers based on porphyrins have been a subject of great interest for photodynamic therapy (PDT) and photodynamic killing of bacteria due to their unique photophysical properties, high photostability, bio-compatibility, lowdark toxicity and high molar absorptivity. ${ }^{1-3}$ Moreover, $\pi$-conjugated porphyrin dimers can be utilized as a two-photon absorbing (TPA) sensitizer because they exhibit the properties of high TPA cross-section and high singlet oxygen efficiency. ${ }^{4-8}$

The photochemical process for both PDT and bacteria killing involves the excitation of a photosensitizing agent with visible light and an energy transfer from an excited photosensitizer to the surrounding triplet oxygen to convert it into singlet oxygen $\left({ }^{1} \mathrm{O}_{2}\right) \cdot{ }^{9-11}$ Singlet oxygen is highly reactive species and exerts a cytotoxic effect inducing cell death and destruction of tumors for PDT and inactivation of bacteria. Therefore, the high ${ }^{1} \mathrm{O}_{2}$ production efficiency is one of the important considerations in the design of a suitable photosensitizer and this can be realized by having a sensitizer with a high intersystem crossing (ISC) ability. ${ }^{1-3}$ ISC can be enhanced by incorporating heavy halogen atoms into a sensitizer such as iodine and bromine that will facilitate the spin-orbit coup-

\footnotetext{
${ }^{a}$ Department of Chemistry, Bilkent University, Bilkent, Ankara, 06800, Turkey. E-mail:dtuncel@fen.bilkent.edu.tr

${ }^{b}$ Institute of Materials Science and Nanotechnology, Bilkent University, Bilkent, Ankara, 06800, Turkey

$\dagger$ Electronic supplementary information (ESI) available: ${ }^{1} \mathrm{H}$ and ${ }^{13} \mathrm{C}$ NMR spectra of compounds reported here, ESI-mass spectra, and UV-vis absorbance spectra of oxidation of DPBF in the presence of photosensitizers. CCDC 1412619 and 1412620. For ESI and crystallographic data in CIF or other electronic format see DOI: $10.1039 / \mathrm{c} 5$ ob01435b

\$These two authors contributed equally to this work.
}

ling. ${ }^{12}$ However, recently it was also reported that a sulfur atom is capable of increasing the ISC efficiency when BODIPY (4,4-difluoro-4-bora-3a,4a-diaza-s-indacene) was functionalized with thiophene. ${ }^{12-16}$

Although there are some examples in the literature regarding the polymeric meso-aryl linked thienylene porphyrin mainly utilized in the area of optoelectronics, ${ }^{17,18}$ to the best of our knowledge, the singlet oxygen generation abilities of these thiophene containing porphyrins have not been studied. Using hydrophilic, preferably, water soluble oligomeric or polymeric photosensitizers one can also benefit from the accumulation of these species in the tumorous tissue through the enhanced permeation retention effect (EPR) for the PDT process. ${ }^{19}$

In this context, we report the synthesis and photophysical properties of new oligomeric and polymeric meso-aryl linked (2,5-thienylene)-porphyrin derivatives with mono and bithiophene units, namely, oligo-5-phenyl(2,5-thienylene)-10,15,20tri(3,5-di-O-TEG-phenyl)-porphyrin $\quad\left(\mathbf{O T T}_{\mathbf{1}} \mathbf{P}\right)$, oligo-5-phenyl(2,5'-bithienylene)-10,15,20-tri(3,5-di-O-TEG-phenyl) porphyrin $\left(\mathbf{O T T}_{2} \mathbf{P}\right)$, and poly-5,15-diphenyl(2,5'-dithienylene)-10,20di(3,5-di-O-TEG-phenyl) porphyrin (PTTP). The sulfur atom on the thiophene molecule eases the intersystem crossing through the heavy atom effect and hence increases the singlet oxygen generation. TEG groups were attached to increase the solubility of these compounds and ideally render their water-solubility. Moreover, the increased molecular weight of the oligomers and polymers will enhance the effective permeation retention.

\section{Results and discussion}

Our target porphyrin precursors for the synthesis of oligomeric and polymeric porphyrins are $\mathbf{P} \mathbf{1}$ and $\mathbf{P} 2$, respectively. 
The synthesis of substituted porphyrins such as P1 and P2 using a one pot synthetic method results in low yield and undesired side products. One alternative to this method is to first synthesize dipyrromethane as a precursor which improves the yield of the desired product. ${ }^{20,21}$ The synthesis of dipyrromethane involves $[2+2]$ condensation reaction between a pyrrole and an aldehyde in the presence of catalytic amounts of acid..$^{20}$ To obtain high yield in this reaction, there are important precautions that have to be taken. First, the choice of an acid is very important. Boron trifluoride diethyl etherate $\left(\mathrm{BF}_{3} \cdot \mathrm{Et}_{2} \mathrm{O}\right)$ and trifluoro acetic acid (TFA) are the two main acid catalysts used in the synthesis of dipyrromethane. Although $\mathrm{BF}_{3} \cdot \mathrm{Et}_{2} \mathrm{O}$ was reported to give higher yield, the amount of side products (N-confused dipyrromethane) is much lower with TFA. Secondly, the sequence of addition of the reactants determines the amount ratio between the dipyrromethane and the higher pyrrolic oligomers. Dipyrromethane is obtained as a major product if the acid is added after stirring pyrrole and aldehyde for some time. Third, pyrrole should be freshly distilled and used in large excess to suppress the polymerization of the product. Lindsey reported that 25 equiv. of pyrrole and 0.1 equiv. of the acid relative to the aldehyde give the optimum yield. $^{22}$

Considering all these precautions dipyrromethane DP1 and DP2 were synthesized in good yield as shown in Scheme $2 .^{23}$ After removing excess pyrrole under reduced pressure, the residue was purified by column chromatography using DCM : $\mathrm{Et}_{3} \mathrm{~N}$ (20:0.1). Pure DP1 was obtained after recrystallization from the ethanol-water mixture in $56 \%$ yield.

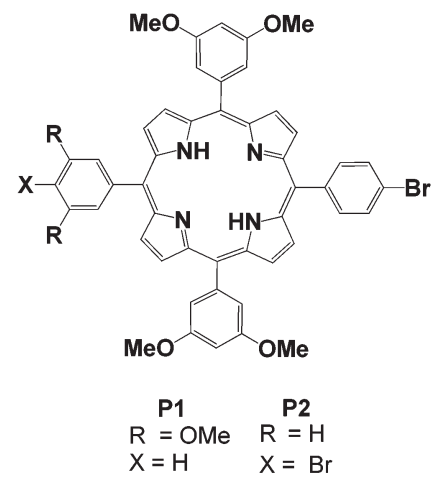

Scheme 1 Porphyrin precursors for the synthesis of dimeric and polymeric porphyrins.
Attempts to purify DP2 by column chromatography failed because the $R_{\mathrm{f}}$ values of DP2 and other pyrrolic compounds were very close. We were fortunate to find out that DP2 crystallizes out with cold $n$-hexane. The pure product was obtained after several washings with $n$-hexane in $22 \%$ yield.

In both ${ }^{1} \mathrm{H}$-NMR of DP1 and DP2 the characteristic $-\mathrm{NH}$ pyrrolic peak at around 8 ppm was observed. In addition, the singlet peak at $5.4 \mathrm{ppm}$ shows the methine proton and thus confirms the formation of dipyrromethane. The singlet peak at $3.7 \mathrm{ppm}$ in the ${ }^{1} \mathrm{H}-\mathrm{NMR}$ of compound DP1 confirms the presence of methoxy $\left(-\mathrm{OCH}_{3}\right)$ groups and this can be used to distinguish DP1 from DP2. The integration values suggest the exact number of protons in DP2 and DP1. Compounds DP2 and DP1 were further characterized with an ESI mass spectrometer to give their mass to charge ratios as 301 and 282, respectively, which agree with the theoretical values. Elemental analysis data from the Experimental section of DP2 and DP1 agree with the theoretical data confirming the structures of DP2 and DP1.

For the synthesis of $\mathbf{P 1}$ and $\mathbf{P 2}$ we have employed four of those routes shown in the reaction in Scheme 3. Because porphyrin synthesis starting from dipyrromethane is reported to give a higher yield, we started the synthesis of $\mathbf{P 1}$ and $\mathbf{P 2}$ from the previously synthesized dipyrromethanes DP2 and DP1 (routes 1, 2 and 3). The reaction was carried out at very low concentrations of the reactants (high dilution method) to facilitate the ring formation and to prevent polymerization of the dipyrromethane. We were expecting three different porphyrin products from these reactions, namely, P1, P2 and P3. However, other porphyrin side products (P4, P5 and P6) were also observed in all three reactions. The formation of these unexpected porphyrins can be attributed to the scrambling of the reactants during the porphyrin ring formation when a strong acid is used as the catalyst. ${ }^{24,25}$

We later tried TFA as the acid catalyst to obtain the desired product selectively but the yield was extremely low. The separation of porphyrin products by column chromatography was extremely tedious especially the cis and trans isomers (P5 and P2) as their $R_{\mathrm{f}}$ values happen to be very close. Therefore, their separation could only be achieved with very long and wide diameter columns. During column chromatography, a very small amount of triethyl amine was added to achieve better separation. Although a mixture of products was obtained, compound $\mathbf{P} 2$ was obtained in the highest yield in both reactions albeit route 2 produced a slightly higher yield of $\mathbf{P} 2$.
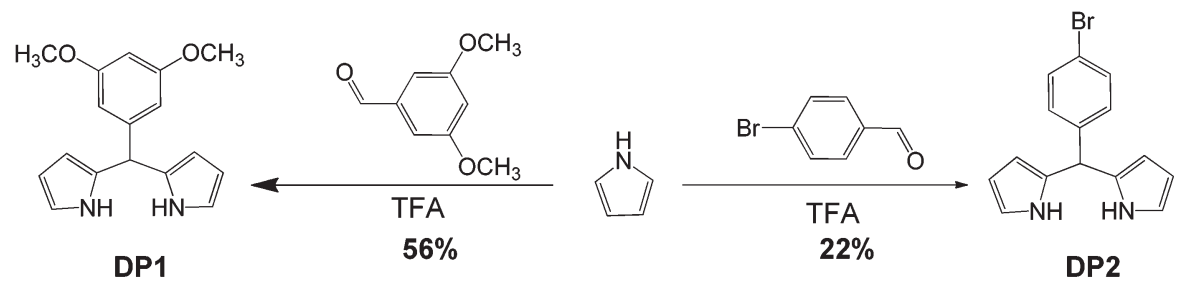

Scheme 2 Synthesis of DP1 and DP2. 


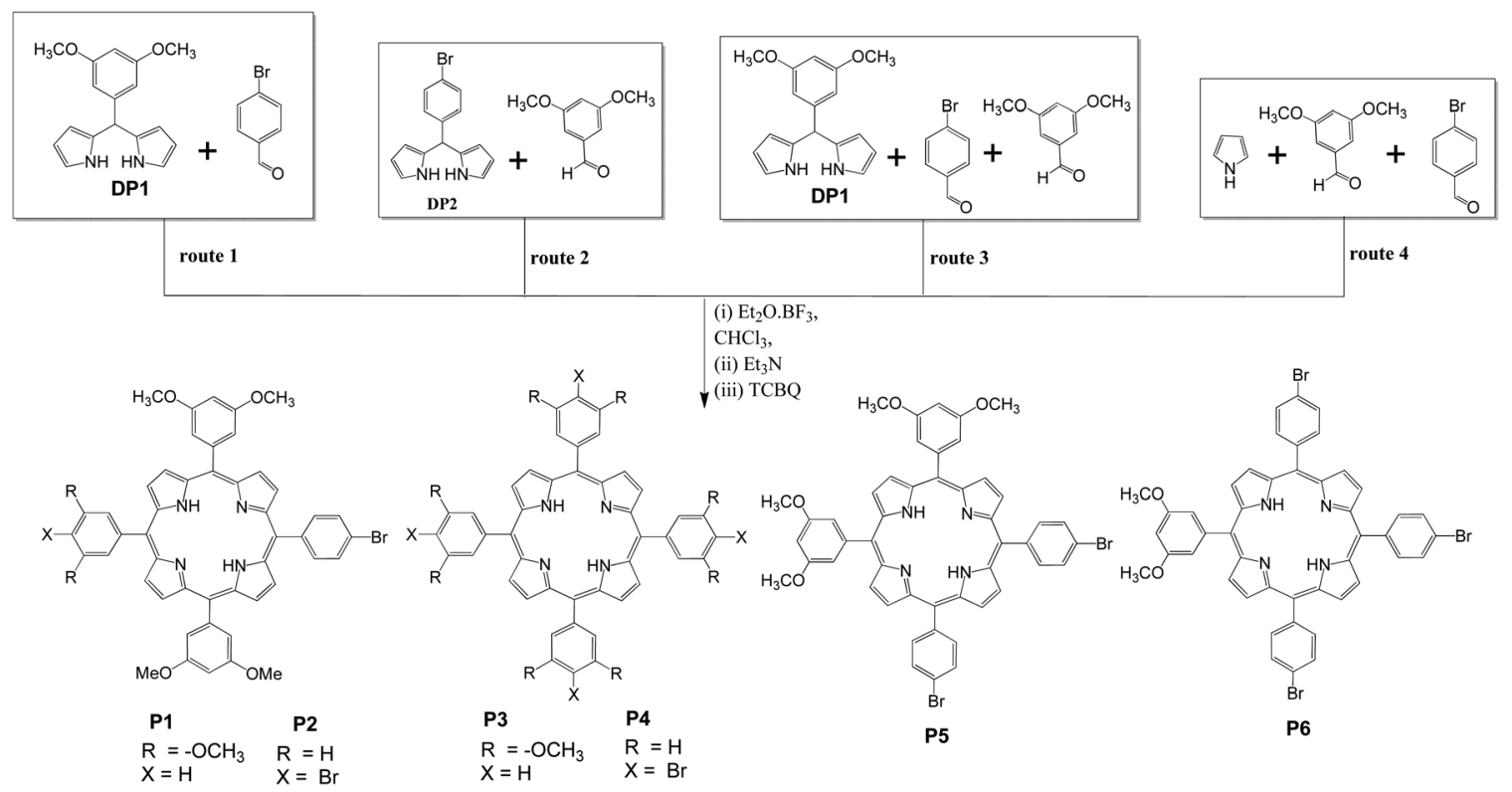

Scheme 3 Four different synthetic routes for the synthesis of porphyrin precursors.

To increase the yield of $\mathbf{P 1}$ we took route 3 in which a mixture of DP2 and $p$-bromo benzaldehyde and 3,5-dimethoxy benzaldehyde was used. This route produced $\mathbf{P 1}$ in $15 \%$ yield besides other porphyrin derivatives.

Since a low yield was obtained for P1 and P2 and all porphyrin side products formed when we started with dipyrromethanes, we changed our synthetic strategy to one pot synthesis (route 4) i.e. by mixing freshly distilled pyrrole, $p$-bromo benzaldehyde and 3,5-dimethoxy benzaldehyde. This route produced all six porphyrin derivatives including P1 and P2. P2 was obtained in higher yield $(26 \%)$ than the others. Table 1 summarizes the yields of porphyrin derivatives obtained from the 4 different reaction routes.

All six porphyrin derivatives were first characterized by ${ }^{1} \mathrm{H}$ NMR spectroscopy. It is quite difficult to distinguish the trans(P2) and cis-(P5) and meso-phenyl porphyrins as their ${ }^{1} \mathrm{H}$ and ${ }^{13} \mathrm{C}$ NMR spectra exhibited identical chemical shifts and splitting patterns. However, we were able to grow suitable crystals and determine their X-ray crystal structures to authenticate them.

Then $\mathbf{P 1}$ and $\mathbf{P 2}$ were treated with $\mathrm{BBr}_{3}$ in $\mathrm{CH}_{2} \mathrm{Cl}_{2}$ for the demethylation of the methoxy groups followed by metallation with $\mathrm{Zn}(\mathrm{OAc})_{2}{ }^{26,27}$ and finally substitution of -OH groups with

Table 1 Yields of porphyrin derivatives obtained from 4 different reaction routes

\begin{tabular}{lrrrrrr}
\hline \% Yield & P1 & P2 & P3 & P4 & P5 & P6 \\
\hline Route 1 & 2 & 16 & 2 & 2 & 5 & 3 \\
Route 2 & 3 & 18 & 2 & 1 & 8 & 2 \\
Route 3 & 15 & 2 & 7 & 2 & 1 & 2 \\
Route 4 & 13 & 26 & 5 & 3 & 10 & 3
\end{tabular}

tri(ethylene glycol) (TEG) monotosylate afforded 5-( $p$-bromophenyl)-10,15,20-tri ( $m$-di-O-TEG-phenyl)porphyrin (Porphyrin 1) and 5,15-di( $p$-bromophenyl)-10,20-di( $m$-di-O-TEG-phenyl)porphyrin (Porphyrin 2) as shown in Scheme 4. Compounds P1-OH, P2-OH, their Zn-inserted versions and Porphyrin $\mathbf{1}$ and 2 were characterized thoroughly by ${ }^{1} \mathrm{H}$ and ${ }^{13} \mathrm{C}$ NMR spectroscopy, ESI-MS and elemental analysis. The results agree with the expected structures.

The oligomers, $\mathbf{O T T}_{\mathbf{1}} \mathbf{P}$ and $\mathbf{O T T}_{\mathbf{2}} \mathbf{P}$ and the polymer, PTTP were synthesized by palladium-catalyzed Stille and Suzuki coupling reactions as shown in Scheme 5. Monomeric porphyrins were metallated by inserting $\mathrm{Zn}$ before carrying out the Pd-catalysed cross-coupling reactions as palladium might coordinate with the core of porphyrin if they are in their freebase form. The oligomers can be dissolved in $\mathrm{MeOH}, \mathrm{CHCl}_{3}$, DMF and THF easily while the polymer is relatively insoluble in $\mathrm{MeOH}$ but can be dissolved in $\mathrm{CHCl}_{3}$, THF and DMF respectively. Their structures were characterized by spectroscopic techniques including ${ }^{1} \mathrm{H}$ NMR, ${ }^{13} \mathrm{C}$ NMR, MS-ESI and elemental analysis. In the ${ }^{1} \mathrm{H}$ NMR spectra of $\mathbf{O T T}_{\mathbf{1}} \mathbf{P}, \mathbf{O T T}_{2} \mathbf{P}$ and PTTP, the significant downfield and upfield displacements of protons with respect to their relevant monomers have been observed with additional proton resonances of thiophene units and their elemental analyses results are consistent with the expected ones. The MS-ESI mass spectra of $\mathbf{O T T}_{\mathbf{1}} \mathbf{P}$ and $\mathbf{O T T}_{2} \mathbf{P}$ showed pseudo-molecular ion peaks at $\mathrm{m} / \mathrm{z}=1605$; $[\mathrm{M}+2 \mathrm{H}]^{2+}$ and $m / z=1646.5872[\mathrm{M}+2 \mathrm{H}]^{2+}$ respectively, supporting the proposed formula for the compounds.

We have attempted to determine the molecular weight of PTTP by GPC in relation to the polystyrene standard in THF. The number average $\left(M_{\mathrm{n}}\right)$ and weight average $\left(M_{\mathrm{w}}\right)$ molecular weights of the polymer were found to be 3109 and 3549 Da respectively with a polydispersity index (PDI) of 1.21. The values 

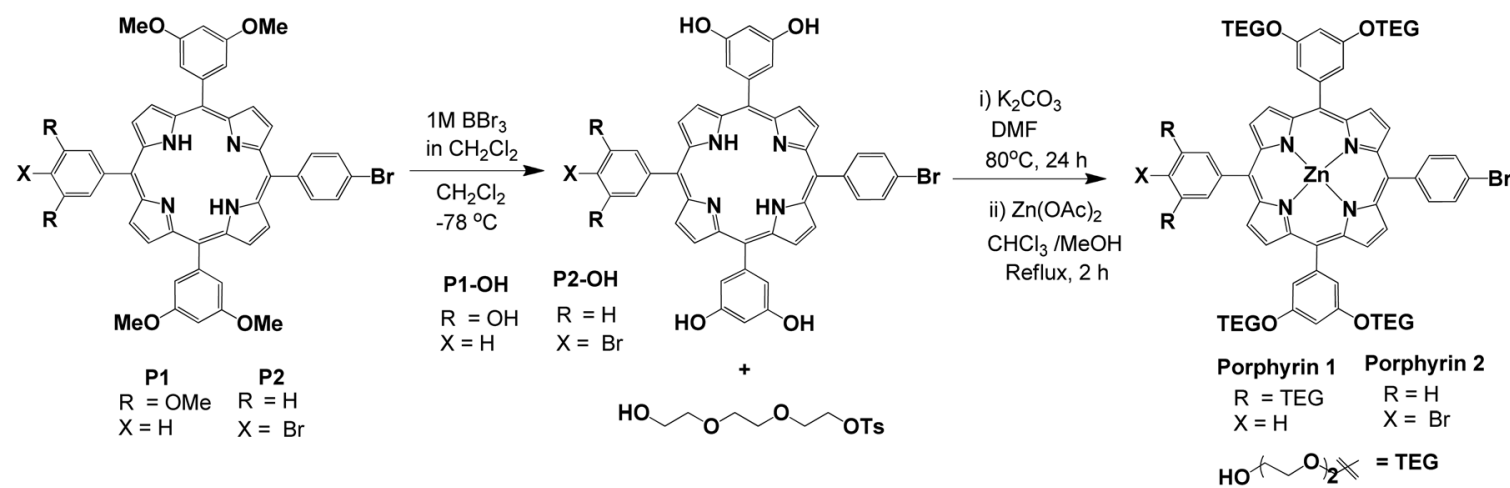

Scheme 4 Synthetic route of Porphyrin 1 and 2.

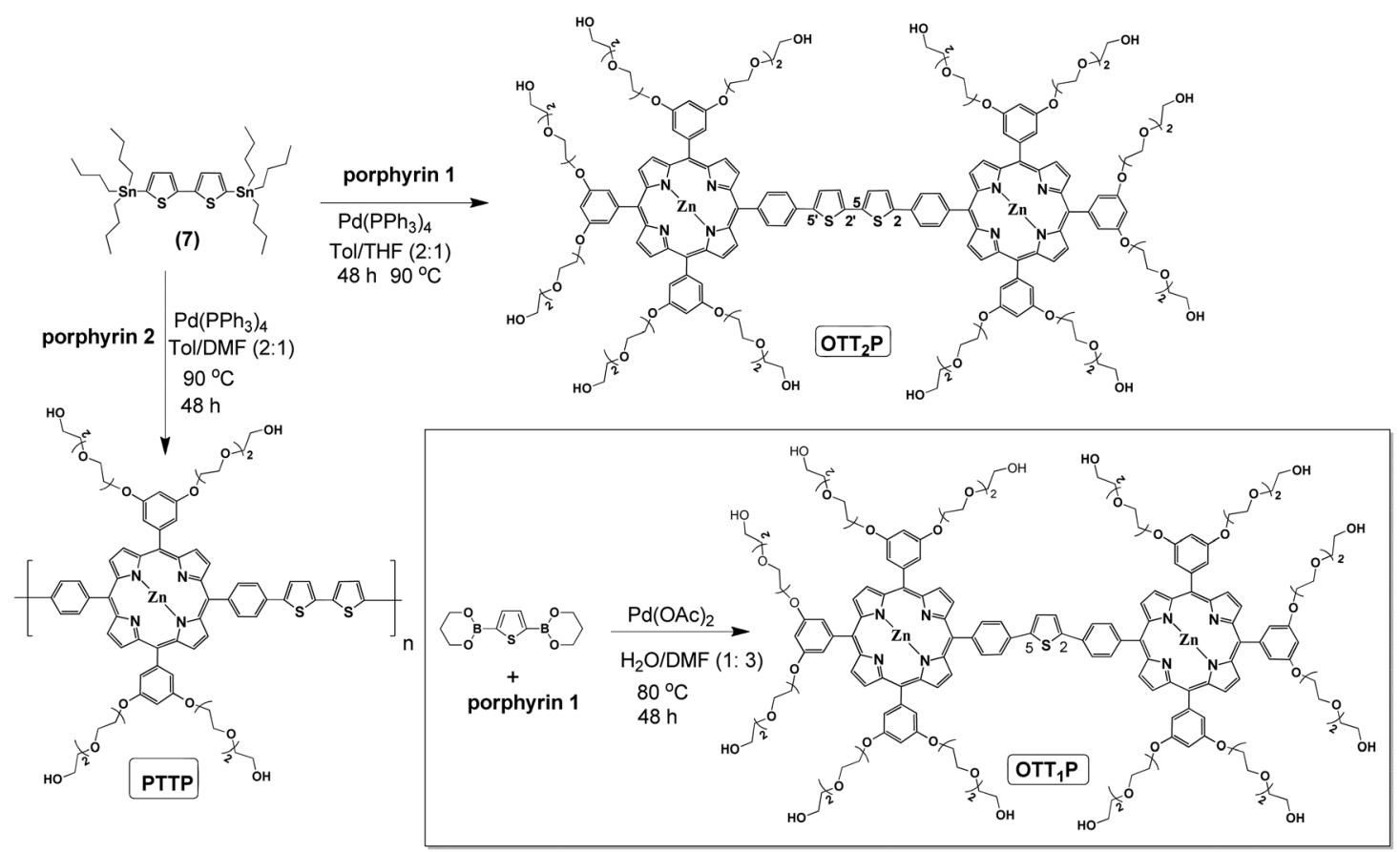

Scheme 5 Synthesis of Zn(॥) oligo- and poly(2,5-thienylene)porphyrins.

are lower than the expected values because of the difficulty of molecular weight determination of rigid polymers like this one.

The optical properties of porphyrin derivatives were investigated by UV-vis absorbance and fluorescence spectroscopy and the results are tabulated in Table 2. Fig. 1a displays the UV-vis absorption spectra of OTT $_{1} \mathbf{P}$, OTT $_{2} \mathbf{P}$, PTTP as well as Porphyrins 1 and 2 in chloroform. Both Porphyrin 1 and 2 exhibited a sharp Soret band at $426 \mathrm{~nm}$ and two weak Q-bands at 555 and $595 \mathrm{~nm}$ as typical absorption peaks of zinc porphyrin compounds. As expected, the Soret band of poly- and oligomers is broadened compared with monomers due to the presence of thiophene units.

The excitation of compounds OTT $_{1} \mathbf{P}, \mathbf{O T T}_{2} \mathbf{P}$ and PTTP in $\mathrm{CHCl}_{3}$ at $426 \mathrm{~nm}$ (Soret band) resulted in fluorescence emis- sion above $600 \mathrm{~nm}$ as the characteristic of porphyrin with two vibrational bands (Fig. 1b). 5,8,26 The mono- and oligomers show two emission peaks at 604 and $654 \mathrm{~nm}$ and no emission peak of the thiophene unit is detected. This result reveals that there is an effective energy transfer from the thiophene unit to the porphyrin unit. $^{17,18}$ The molar absorptivity of OTT $_{\mathbf{1}} \mathbf{P}$, $\mathbf{O T T}_{2} \mathbf{P}$ and PTTP in $\mathrm{CHCl}_{3}$ and $\mathrm{MeOH}$ solution were $1.3 \times 10^{6}$ $(\mathrm{MeOH}), 9.4 \times 10^{5}(\mathrm{MeOH})$ and $5.1 \times 10^{5}$ (in $\mathrm{CHCl}_{3}$, per repeating unit). The photoluminescence quantum yields of P1, P2, $\mathbf{O T T}_{1} \mathbf{P}, \mathbf{O T T}_{2} \mathbf{P}$ and PTTP in relation to tetraphenylporphyrin $\left(\mathrm{H}_{2} \mathrm{TPP}\right)\left(\Phi_{\mathrm{PL}}=0.11\right)$ as the reference standard are also shown in Table 2.

Singlet oxygen production efficiency of the porphyrin-based photosensitizers were determined through an established 
Table 2 Optical properties of porphyrin derivatives in $\mathrm{CHCl}_{3}{ }^{a}$ and $\mathrm{MeOH}^{b}$

\begin{tabular}{lllll}
\hline $\begin{array}{l}\text { Compound } \\
\text { (acronym) }\end{array}$ & $\begin{array}{l}\varepsilon^{a}\left(\mathrm{M}^{-1} \mathrm{~cm}^{1}\right) \\
(\text { Soret band) }\end{array}$ & $\begin{array}{l}\varepsilon^{b}\left(\mathrm{M}^{-1} \mathrm{~cm}^{-1}\right) \\
(\text { Soret band })\end{array}$ & $\% \Phi_{\mathrm{PL}}{ }^{a}$ & $\% \Phi_{\mathrm{PL}}{ }^{b}$ \\
\hline Porphyrin 1 & $6.3 \times 10^{5}$ & $2.7 \times 10^{5}$ & 9.6 & 7.1 \\
Porphyrin 2 & $3.5 \times 10^{5}$ & $6.4 \times 10^{5}$ & 5.4 & 5.4 \\
OTT $_{\mathbf{1}} \mathbf{P}$ & $1.3 \times 10^{6}$ & $1.0 \times 10^{6}$ & 15.4 & 14.9 \\
OTT $_{2} \mathbf{P}$ & $9.4 \times 10^{5}$ & $1.0 \times 10^{6}$ & 6.8 & 5.7 \\
PTTP & - & $5.1 \times 10^{5 c}$ & - & 9.7
\end{tabular}

${ }^{a}$ In $\mathrm{MeOH} .{ }^{b}$ In $\mathrm{CHCl}_{3} .{ }^{c}$ Per repeat unit. Photoluminescent quantum yield determined relative to $\mathrm{H}_{2} \mathrm{TPP}\left(\Phi_{\mathrm{PL}}=0.11\right.$ in toluene $)-\operatorname{not}$ soluble in $\mathrm{MeOH}$.

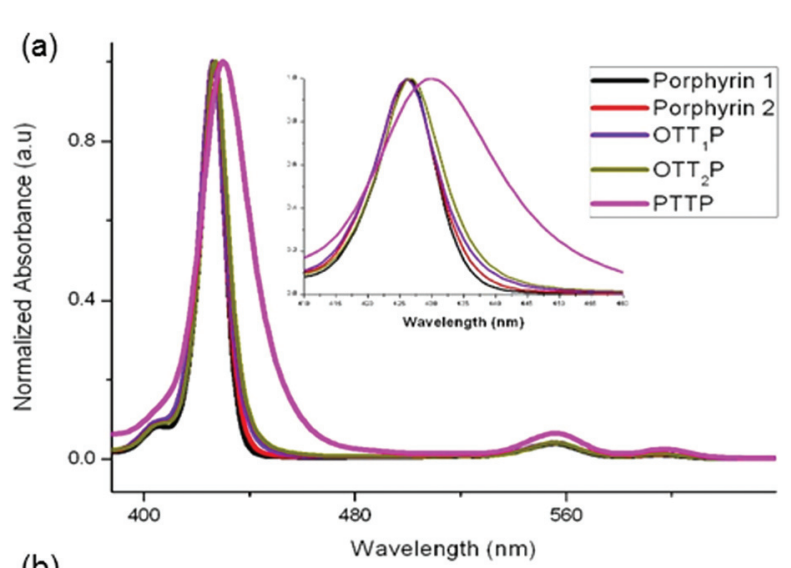

(b)

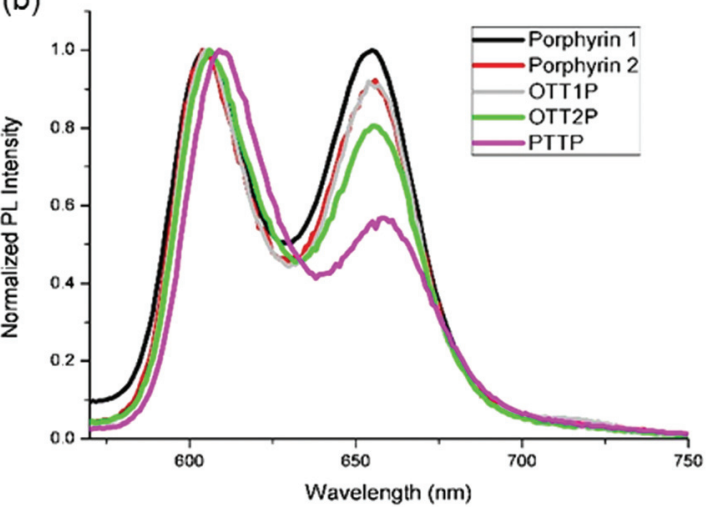

Fig. 1 (a) Normalized absorption spectra of the compounds in $\mathrm{CHCl}_{3}$. The inset of the figure shows the focused version of the Soret band (b) Normalized emission spectra of the compounds in $\mathrm{CHCl}_{3}\left(\lambda_{\text {exc }}\right.$. at $426 \mathrm{~nm})$.

photochemical method, using 1,3-diphenylisobenzofuran (DPBF) as an efficient ${ }^{1} \mathrm{O}_{2}$ quencher in combination with accurate, time-dependent spectrophotometric determination of DPBF concentration. ${ }^{13,14,27}$ DPBF was used as a chemical monitor in order to estimate the ${ }^{1} \mathrm{O}_{2}$ photogeneration quantum yield of the established photosensitizers, OTT $_{\mathbf{1}} \mathbf{P}$, $\mathbf{O T T}_{2} \mathbf{P}$ and PTTP in DMF (Scheme 1). The relative $\Phi_{\Delta}{ }^{1} \mathrm{O}_{2}$ generation efficiency was determined in comparison with tetraphenylporphyrin (TPP) by monitoring the reduced loss of absorbance of DPBF (at $418 \mathrm{~nm}$ in DMF) with the increasing irradiation time. ${ }^{13,28}$ The relationship between DPBF's absorption value ratio $\left(A / A_{0}\right)$ and irradiation time indirectly reflected the ${ }^{1} \mathrm{O}_{2}$ yield of those established photosensitizers compared with Porphyrin 1 (Fig. S43 and S44†).

The following eqn (1) was used to calculate the singlet oxygen quantum yield of Porphyrin 1, Porphyrin 2, OTT $\mathbf{1}$, OTT $_{2} \mathbf{P}$ and PTTP:

$$
\Phi\left({ }^{1} \mathrm{O}_{2}\right)^{\text {Por }}=\Phi\left({ }^{1} \mathrm{O}_{2}\right)^{\mathrm{TPP}} m^{\text {Por }} / m^{\mathrm{TPP}} \times F^{\mathrm{TPP}} / F^{\text {Por }}
$$

where the superscripts 'Por' and 'TPP' denote Porphyrin 1, Porphyrin 2, OTT $\mathbf{1} \mathbf{P}, \mathbf{O T T}_{\mathbf{2}} \mathbf{P}$ and PTTP and tetraphenylporphyrin (TPP), respectively; $\Phi\left({ }^{1} \mathrm{O}_{2}\right)$ is the singlet oxygen quantum yield, $m$ is the slope of a plot of difference in change in absorbance of DPBF (at $418 \mathrm{~nm}$ ) with the irradiation time (see ESI, Fig. S44 $\dagger$ ) and $F$ is the absorption correction factor, which is given by $F=1-10^{-\mathrm{OD}}$ (OD at the irradiation wavelength). ${ }^{13}$

Among these PTTP was found to be the most productive as it could be seen with the increase of the line slope. The order of relative singlet oxygen production yields can therefore be derived as: Porphyrin $\mathbf{1}<$ Porphyrin $\mathbf{2}<\mathbf{O T T}_{\mathbf{2}} \mathbf{P}=\mathbf{O T T}_{\mathbf{1}} \mathbf{P}<\mathbf{P T T P}$ and their photogenerating ${ }^{1} \mathrm{O}_{2}$ abilities might be significantly affected by the conjugation of the thiophene units between the porphyrins. The relative magnitude of singlet oxygen generation efficiency was examined by means of tetraphenylporphyrin (TPP) as a reference $\left(\Phi_{\Delta(\mathrm{TPP})}=0.60 \mathrm{in} \mathrm{DMF)}\right.$ (Table 3).

\section{Conclusions}

In this study, porphyrin-thiophene based compounds were synthesized and their singlet oxygen production efficiencies have been studied in a polar solvent. The results indicated that the presence of sulfur atoms on thiophene units, probably facilitates the intersystem crossing due to spin-orbit coupling and thus, in turn, causes an increase in the singlet oxygen production efficiency. Moreover, it was found that the ability of singlet oxygen generation of the polymer is higher than the oligomers followed by monomers. Although we have attached TEG groups to porphyrin derivatives to increase their water solubility, among them, only monomeric and dimeric porphyrins were sparingly soluble in water. These porphyrin based compounds can be used as photosensitizers for photodynamic therapy and photodynamic killing applications.

Table 3 Singlet oxygen quantum yield $\left(\Phi_{\Delta}\right)$ in DMF with respect to tetraphenylporphyrin (TPP)

\begin{tabular}{lllllll}
\hline Sample & TPP & Porphyrin 1 & Porphyrin 2 & OTT $_{\mathbf{1}} \mathbf{P}$ & OTT $_{2} \mathbf{P}$ & PTTP $^{2}$ \\
\hline$\Phi_{\Delta}$ & 0.60 & 0.65 & 0.78 & 0.80 & 0.80 & 0.88
\end{tabular}




\section{Experimental section}

\section{Materials and methods}

Solvents were dried and distilled before use. All reactions were performed under air unless otherwise stated. Unless otherwise mentioned, all reagents were used as received from commercial suppliers. Thin layer chromatography was performed on $\mathrm{SiO}_{2} 60$ F-254 plates and flash column chromatography was carried out using $\mathrm{SiO}_{2} 60$ (particle size 0.040-0.055 mm, 230-400 mesh). NMR spectra $\left({ }^{1} \mathrm{H}\right.$ at $400 \mathrm{MHz}$ and ${ }^{13} \mathrm{C}$ at $100 \mathrm{MHz}$ ) were recorded on a Bruker DPX-400 spectrometer in $\mathrm{CDCl}_{3}$ and DMSO- $\mathrm{d}_{6}$ solvent and TMS $(\delta=0.00 \mathrm{ppm})$ as an internal standard. Chemical shifts were reported as $\delta$ values in ppm as referenced to TMS. The elemental composition of the samples was determined using a FLASH 2000 Organic Elemental/CHNS-O Analyzer. The mass spectra were obtained with Agilent 6224 High Resolution Mass Time-of-Flight (TOF) LC/ MS using an electrospray ionization method. UV-VIS absorption spectra were recorded on a UV-vis spectrophotometer (Cary UV-vis) with $1 \mathrm{~cm}$ path length quartz cuvettes in the spectral range of 300-800 $\mathrm{nm}$. Emission spectra were recorded on a fluorescence spectrophotometer (Cary Eclipse Fluorescent spectrophotometer). The quantum yields of fluorescence of the compounds were determined using tetraphenylporphyrin (TPP) as the standard (in toluene it was 0.11). ${ }^{18}$ The quantum yields were calculated from the integrals under the emission curves of the probe and the standard and corrected for the different absorptions at the excitation wavelength. For this purpose, a series of diluted solutions for each compound were prepared and their absorbance and integrated fluorescence intensities were recorded at each concentration. The fluorescence spectra were recorded by exciting the maximum of the long-wavelength absorption band. ${ }^{9}$ For the measurement of the extinction coefficients about $1.5 \mathrm{mg}$ of each compound was dissolved into $25 \mathrm{~mL}$ of $\mathrm{CHCl}_{3}$ and $\mathrm{MeOH}$. From this stock solution further dilutions with different concentrations $\left(10^{-8}\right.$ to $\left.10^{-9} \mathrm{M}\right)$ were made. The absorption spectra for each dilution were then measured, and their extinction coefficients were determined from the slope of absorbance versus concentration. For the singlet oxygen generation experiment, an aerated solution of 1,3-diphenylisobenzofuran (DPBF) $(20 \mu \mathrm{M})$ and photosensitizer $(0.5 \mu \mathrm{M})$ in DMF $(2 \mathrm{~mL})$ was irradiated at $420 \mathrm{~nm}$ under a Spectral Products monochromator integrated xenon lamp at $25{ }^{\circ} \mathrm{C}$ for 30 second intervals. Reaction of DPBF with ${ }^{1} \mathrm{O}_{2}$ was monitored by the decreasing intensity of the absorption band at $418 \mathrm{~nm}$ over time (see ESI, Fig. S43†). Irradiation of aerated DPBF solution without a photosensitizer gave no reduction in intensity of the $418 \mathrm{~nm}$ absorption band. The absorption of the photosensitizer was first measured because the Soret band of porphyrin overlaps with the absorption maxima of 1,3-diphenylisobenzofuran (DPBF). The same photosensitizer solution was used to dissolve DPBF to obtain the desired concentration of DPBF. Computer software was used to subtract the photosensitizer spectrum from the combined spectra of the photosensitizer and the trap. The log plot of the normalized absorption maxima $v s$. time was plotted and the slope gave the comparative singlet oxygen generation of the photosensitizers with respect to tetraphenylporphyrin (TPP) (see ESI, Fig. S43†).

$(2,2$ '-((3,5-Dimethoxyphenyl)methylene)bis( $1 H$-pyrrole $))$ (Dipyrromethane, DP1). 3,5-Dimethoxy benzaldehyde $(1.00 \mathrm{~g}$, $6.02 \mathrm{mmol}$ ) and freshly distilled pyrrole $25 \mathrm{~mL}(24.3 \mathrm{~g}$, $361 \mathrm{mmol}$ ) were placed in a two-necked round bottom flask under a nitrogen atmosphere. The mixture was heated to $50{ }^{\circ} \mathrm{C}$. After removing the heat source, trifluoroacetic acid (TFA) $46 \mu \mathrm{L}(0.0686 \mathrm{~g}, 0.602 \mathrm{mmol})$ was added immediately. After 10 minutes the solution was quenched with $6 \mathrm{~mL}$ of $0.1 \mathrm{M} \mathrm{NaOH}$. The solvents and the unreacted pyrrole were removed under reduced pressure. The residue was purified using column chromatography with $\mathrm{DCM}: \mathrm{Et}_{3} \mathrm{~N}(20: 1)$ as the eluent. The yellow oily product from the column was recrystallized by dissolving in hot ethanol followed by addition of water. The precipitate was collected by suction filtration to yield a light brown solid substance (945 mg, 56\%). Melting point (ethanol- $\mathrm{H}_{2} \mathrm{O}$ ): 92.5-93.3 ${ }^{\circ} \mathrm{C}$.

${ }^{1} \mathrm{H}$ NMR (400 MHz, $\left.\mathrm{CDCl}_{3}, 25{ }^{\circ} \mathrm{C}\right): \delta 3.76(\mathrm{~s}, 6 \mathrm{H}), 5.43$ $(\mathrm{s}, 1 \mathrm{H}), 5.98(\mathrm{~d}, 2 \mathrm{H}, J=4.0 \mathrm{~Hz}), 6.17(\mathrm{t}, 2 \mathrm{H}, J=5.6 \mathrm{~Hz}), 6.38$ $(\mathrm{s}, 1 \mathrm{H}), 6.41(\mathrm{~s}, 2 \mathrm{H}), 6.72(\mathrm{~d}, 2 \mathrm{H}, J=4.0 \mathrm{~Hz}), 7.95(\mathrm{br}, 2 \mathrm{H}$, $\mathrm{N}-\mathrm{H}) ;{ }^{13} \mathrm{C} \mathrm{NMR}\left(100 \mathrm{MHz}, \mathrm{CDCl}_{3}, 25{ }^{\circ} \mathrm{C}\right): \delta 161.00,144.46$, 132.10, 117.18, 108.46, 107.21, 106.72, 98.82, 55.31, 44.32. Elemental analysis: calcd for $\mathrm{C}_{17} \mathrm{H}_{18} \mathrm{~N}_{2} \mathrm{O}_{2}$ : C 72.32, $\mathrm{H}$ 6.43, $\mathrm{N}$ 9.92, O 11.33; found: $\mathrm{C} 72.79, \mathrm{H} 6.32, \mathrm{~N} 9.84$. ESI-MS $\mathrm{m} / \mathrm{z}$ calcd for $\mathrm{C}_{17} \mathrm{H}_{18} \mathrm{~N}_{2} \mathrm{O}_{2}$ : 282.14; found 281.12 [M - H].

2,2'-((3,5-Dibromophenyl)methylene)bis(1H-pyrrole) (Dipyrromethane, DP2). p-Bromo benzaldehyde (2.00 g, $10.8 \mathrm{mmol})$ and freshly distilled pyrrole $50 \mathrm{~mL}(48.5 \mathrm{~g}, 723 \mathrm{mmol})$ were placed into a two-necked round bottom flask under a nitrogen atmosphere. The mixture was heated to $50{ }^{\circ} \mathrm{C}$. After removing the heat source, trifluoroacetic acid (TFA) $83 \mu \mathrm{L}(0.124 \mathrm{~g}$, $1.08 \mathrm{mmol}$ ) was added immediately. After 10 minutes the solution was quenched with $11 \mathrm{~mL}$ of $0.1 \mathrm{M} \mathrm{NaOH}$. The solvents and the unreacted pyrrole were removed under reduced pressure to yield a light brown oily product. The residue was purified by recrystallization using $n$-hexane. The precipitate was collected by suction filtration to yield a brownish solid substance (726 mg, 22\%). Melting point (n-hexane): $126-127^{\circ} \mathrm{C}$.

${ }^{1} \mathrm{H}$ NMR (400 MHz, $\left.\mathrm{CDCl}_{3}, 25{ }^{\circ} \mathrm{C}\right): \delta 5.45$ (s, 1H), 5.91 $(\mathrm{d}, 2 \mathrm{H}, J=6.8 \mathrm{~Hz}), 6.17(\mathrm{t}, 2 \mathrm{H}, J=5.6 \mathrm{~Hz}), 6.73(\mathrm{~d}, 2 \mathrm{H}, J=$ $6.8 \mathrm{~Hz}), 7.10(\mathrm{~d}, 2 \mathrm{H}, J=8.4 \mathrm{~Hz}), 7.45(\mathrm{~d}, 2 \mathrm{H}, J=8.4 \mathrm{~Hz}), 7.94$ (br, $2 \mathrm{H}, \mathrm{N}-\mathrm{H}) ;{ }^{13} \mathrm{C} \mathrm{NMR}\left(100 \mathrm{MHz}, \mathrm{CDCl}_{3}, 25{ }^{\circ} \mathrm{C}\right): \delta 141.20$, 132.69, 131.68, 130.13, 117.48, 108.58, 107.44, 43.46. Elemental analysis: calcd for $\mathrm{C}_{15} \mathrm{H}_{13} \mathrm{BrN}_{2}$ : C 59.82, $\mathrm{H}$ 4.35, N 9.30; found: $\mathrm{C} 59.48, \mathrm{H}$ 4.40, $\mathrm{N}$ 9.41. ESI-MS $\mathrm{m} / \mathrm{z}$ calcd for $\mathrm{C}_{15} \mathrm{H}_{13} \mathrm{BrN}_{2}$ : 300.03; found $301.01[\mathrm{M}+\mathrm{H}]^{1}$.

Route 1: Compound DP1 (0.40 g, $1.42 \mathrm{mmol})$ and 4-bromobenzaldehyde $(0.262 \mathrm{~g}, 1.42 \mathrm{mmol})$ were dissolved in distilled chloroform $(1000 \mathrm{~mL})$ and stirred while purging nitrogen for at least 30 minutes and the reaction flask was kept away from light. During stirring, $61 \mu \mathrm{L}(0.0696 \mathrm{~g}, 0.490 \mathrm{mmol})$ of the Lewis acid catalyst $\left(\mathrm{Et}_{2} \mathrm{O} \cdot \mathrm{BF}_{3}\right)$ was added to the reaction mixture under a nitrogen atmosphere. The reaction mixture 
was stirred for 1 hour at room temperature followed by the addition of $79 \mu \mathrm{L}(0.0573 \mathrm{~g}, 0.567 \mathrm{mmol})$ of triethylamine and (0.263 g, $1.07 \mathrm{mmol})$ of TCBQ. The reaction mixture was refluxed for 1 hour. The solution was cooled to room temperature and the volume of the reaction mixture was reduced to ca. $300 \mathrm{~mL}$, filtered through silica gel, and evaporated to dryness. The purple residues were washed with $\mathrm{MeOH}$. The residues were further purified by column chromatography on silica gel using toluene as the eluent to isolate 6 different porphyrin derivatives which were triturated with $\mathrm{MeOH}$ to obtain shiny purple crystals. Yields: P1, 2\%; P2, 16\%; P3, 2\%; P4, 2\%; P5, 5\%; P6, 3\%. Melting points are higher than $300{ }^{\circ} \mathrm{C}$.

Route 2: Compound DP2 $(0.500 \mathrm{~g}, 1.66 \mathrm{mmol})$ and 3,5dimethoxybenzaldehyde $(0.276 \mathrm{~g}, 1.66 \mathrm{mmol})$ were dissolved in distilled chloroform (1000 $\mathrm{mL})$ and stirred while purging nitrogen for at least 30 minutes and the reaction flask was kept away from light. The rest of the procedure is the same as Route 1. Yields: P1, 3\%; P2, 18\%; P3, 2\%; P4, 1\%; P5, 8\%; P6, 2\%.

Route 3: Compound DP1 (0.500 g, $1.77 \mathrm{mmol})$, 4-bromobenzaldehyde $(0.164 \mathrm{~g}, 0.886 \mathrm{mmol})$ and 3,5-dimethoxybenzaldehyde $(0.147 \mathrm{~g}, 0.886 \mathrm{mmol})$ were dissolved in distilled chloroform $(1000 \mathrm{~mL})$ and stirred while purging nitrogen for at least 30 minutes and the reaction flask was kept away from light. The rest of the procedure is the same as Route 1. Yields: P1, 15\%; P2, 2\%; P3, 7\%; P4, 2\%; P5, 1\%; P6, $2 \%$.

Route 4: To $1.5 \mathrm{~L}$ of chloroform were added 3,5-dimethoxybenzeldehyde (1.00 g, (6.01 mmol), 4-bromobenzaldehyde $(1.13 \mathrm{~g}, 6.01 \mathrm{mmol})$ and pyrrole $(0.800 \mathrm{~g}, 12.0 \mathrm{mmol})$ and the reaction flask was covered with aluminum foil. The rest of the procedure is the same as Route 1. Yields: P1, 13\%; P2, 26\%; P3, 5\%; P4, 3\%; P5, 10\%; P6, 3\%.

\section{Characterization of P1 to P6}

P1: ${ }^{1} \mathrm{H}$ NMR (400 MHz, $\left.\mathrm{CDCl}_{3}, 25{ }^{\circ} \mathrm{C}\right): \delta 8.97(\mathrm{~m}, 6 \mathrm{H}), 8.85$ $(\mathrm{m}, 2 \mathrm{H}), 8.15(\mathrm{~d}, 2 \mathrm{H}, J=8 \mathrm{~Hz}), 7.85(\mathrm{~d}, 2 \mathrm{H}, J=8 \mathrm{~Hz}), 7.42$ (s, 6H), 6.95 (s, 3H), 3.98 (s, 18H, -OMe), -2.83 (s, 2H, NH); ${ }^{13} \mathrm{C}$ NMR (100 $\left.\mathrm{MHz}, \mathrm{CDCl}_{3}, 25{ }^{\circ} \mathrm{C}\right): \delta$ 158.88, 143.93, 135.83, 129.91, 113.88, 100.18, 55.63; ESI-MS $\mathrm{m} / \mathrm{z}$ calcd for $\mathrm{C}_{50} \mathrm{H}_{41} \mathrm{BrN}_{4} \mathrm{O}_{6}, 873.7877$; found, 873.24082 [M + H $]^{+}$.

P2: ${ }^{1} \mathrm{H}$ NMR (400 $\left.\mathrm{MHz}, \mathrm{CDCl}_{3}, 25{ }^{\circ} \mathrm{C}\right): \delta 8.95(\mathrm{~d}, 4 \mathrm{H}, J=$ $5.4 \mathrm{~Hz}), 8.80(\mathrm{~d}, 4 \mathrm{H}, J=5.4 \mathrm{~Hz}), 8.10(\mathrm{~d}, 2 \mathrm{H}, J=8.0 \mathrm{~Hz}), 7.95$ $(\mathrm{d}, 2 \mathrm{H}, J=8.0 \mathrm{~Hz}), 7.45(\mathrm{~s}, 4 \mathrm{H}), 6.95(\mathrm{~s}, 2 \mathrm{H}), 3.98(\mathrm{~s}, 12 \mathrm{H}$, -OMe), -2.84 (s, 2H, NH); ${ }^{13} \mathrm{C}$ NMR (100 $\left.\mathrm{MHz} \mathrm{CDCl}_{3}, 25{ }^{\circ} \mathrm{C}\right)$ : $\delta$ 158.90, 143.83, 141.04, 135.81, 129.93, 122.51, 120.16, $118.60,114.80,113.80,100.19,55.62$; ESI-MS $\mathrm{m} / \mathrm{z}$ calcd for $\mathrm{C}_{48} \mathrm{H}_{36} \mathrm{Br}_{2} \mathrm{~N}_{4} \mathrm{O}_{4}, 893.6318$; found, $893.1291[\mathrm{M}+\mathrm{H}]^{+}$. The X-ray crystal structure was also determined (ESI $\dagger$ ); P5: ${ }^{1} \mathrm{H},{ }^{13} \mathrm{C}-\mathrm{NMR}$ spectroscopic and ESI-MS data are similar to P2. The X-ray crystal structure was also determined (ESI $\dagger$ ).

X-ray crystal data for $\mathbf{P 2}$. A saturated solution of $\mathbf{P} 2$ in $\mathrm{CHCl}_{3}$ was exposed to methanol vapour in a closed chamber to grow transparent crystals for X-ray crystal analysis. $\left[\mathrm{C}_{48} \mathrm{H}_{36} \mathrm{Br}_{2} \mathrm{~N}_{4} \mathrm{O}_{4}\right]$, $M=892.63$, monoclinic, space group $P 2_{1} / n$, space group IT number: 14; unit cell parameters: $a$ 15.973(3), $b$ 8.5673(15), $c$ 28.865(5) А, $\alpha$ 90, $\beta$ 93.316(4), $\delta$ 90, $V=3943.4(12) \AA^{3}, Z=4$, $D_{\mathrm{c}}=1.504 \mathrm{~g} \mathrm{~cm}^{-3}, F_{000}=1816$, MoK $\alpha$ radiation, $\lambda=0.71073 \AA$, $\theta_{\max }=25.990^{\circ}, 25461$ reflections collected, 5932 unique $\left(R_{\mathrm{int}}=\right.$ 0.0410 ), final GooF $=1.119, R_{1}=0.0693, \mathrm{w} R_{2}=0.1148$, $R$ indices based on 7741 reflections with $I>2 \sigma(I)$ (refinement on $F^{2}$ ), 562 parameters, 0 restraints. Lp and absorption corrections applied, $\mu=2.108 \mathrm{~mm}^{-1}$.

X-ray crystal data for P5. A saturated solution of P5 in $\mathrm{CHCl}_{3}$ was exposed to methanol vapour in a closed chamber to grow transparent crystals for X-ray crystal analysis. $\left[\mathrm{C}_{48} \mathrm{H}_{36} \mathrm{Br}_{2} \mathrm{~N}_{4} \mathrm{O}_{4}\right]$, $M=892.63$, monoclinic, space group $C \overline{2} / c$, space group IT number: 15; unit cell parameters: $a$ 23.99(3) $b$ 16.08(3) $c$ 10.433(15) $\AA$ А $\alpha 90^{\circ}, \beta 102.51^{\circ}(7), \delta 90^{\circ}, V=3929(11) \AA^{3}, Z=4, D_{\mathrm{c}}=$ $1.509 \mathrm{~g} \mathrm{~cm}^{-3}, F_{000}=1816$, MoK $\alpha$ radiation, $\lambda=0.71073 \AA$, $\theta_{\max }=30^{\circ}, 11841$ reflections collected, 3666 unique $\left(R_{\mathrm{int}}=\right.$ 0.0410 ), final GooF $=1.195, R_{1}=0.0895, \mathrm{w} R_{2}=0.2083$, $R$ indices based on 0.2083 reflections with $I>2 \sigma(I)$ (refinement on $F^{2}$ ), 265 parameters, 0 restraints. Lp and absorption corrections applied, $\mu=2.116 \mathrm{~mm}^{-1}$.

P3: ${ }^{1} \mathrm{H}$ NMR (400 MHz, $\left.\mathrm{CDCl}_{3}, 25{ }^{\circ} \mathrm{C}\right): 8.92(\mathrm{~s}, 8 \mathrm{H}), 8.15$ (d, $8 \mathrm{H}), 7.82$ (d, 8H), 3.98 (s, 24H, -OMe), -2.83 (s, 2H, NH); P4: ${ }^{1} \mathrm{H}$ NMR (400 MHz, $\left.\mathrm{CDCl}_{3}, 25{ }^{\circ} \mathrm{C}\right): \delta 8.92(\mathrm{~s}, 8 \mathrm{H}), 8.15$ (d, $8 \mathrm{H}), 7.82$ (d, 8H), 3.98 (s, 24H, -OMe), -2.83 (s, 2H, -NH); P6: ${ }^{1} \mathrm{H}$ NMR (400 MHz, $\left.\mathrm{CDCl}_{3}, 25{ }^{\circ} \mathrm{C}\right)$ : $\delta 9.02(\mathrm{~m}, 2 \mathrm{H}), 8.82$ $(\mathrm{m}, 6 \mathrm{H}), 8.10$ (d, $6 \mathrm{H}), 7.82(\mathrm{~d}, 6 \mathrm{H}), 7.32(\mathrm{~s}, 2 \mathrm{H}), 3.92(\mathrm{~s}, 6 \mathrm{H}$, -OMe), -2.83 (s, 2H, NH).

P1-OH. To a solution of $\mathbf{P 1}(100 \mathrm{mg}, 0.11 \mathrm{mmol})$ in dry dichloromethane $(25 \mathrm{~mL})$ at $-78{ }^{\circ} \mathrm{C}$ under an argon atmosphere, boron tribromide solution $\left(\mathrm{BBr}_{3}\right.$ solution) $(1 \mathrm{M}$ in dichloromethane, $12 \mathrm{ml}, 33 \mathrm{mmol}$ ) was added. The reaction mixture was stirred at $-78{ }^{\circ} \mathrm{C}$ for 1 hour, and then allowed to warm to room temperature. After the reaction mixture was stirred at room temperature overnight, the reaction mixture was cooled to $0{ }^{\circ} \mathrm{C}$ followed by the addition of $10 \mathrm{~mL}$ of water. The resulting mixture was stirred for 5-10 minutes and the solvents were removed under reduced pressure. The aqueous phase was extracted with ethyl acetate $(5 \times 20 \mathrm{~mL})$ followed by the removal of the solvents under reduced pressure. The solid residue was further washed with chloroform to give $74 \mathrm{mg}$ as purple crystals in $91 \%$ yield. ${ }^{1} \mathrm{H}-\mathrm{NMR}\left(400 \mathrm{MHz}, \mathrm{DMSO}-d_{6}\right.$, $\left.25^{\circ} \mathrm{C}\right): \delta 9.75(\mathrm{~s}, 6 \mathrm{H}, \mathrm{OH}), 8.95-8.83(\mathrm{~m}, 4 \mathrm{H}$, bromophenyl- $\mathrm{H})$, 8.03-8.19 (m, 6H, O-phenyl-H), 6.67-7.09 (m, 3H, p-phenyl-H), -3.00 (s, 2H, pyrrole, NH). ${ }^{13} \mathrm{C}-\mathrm{NMR}\left(100 \mathrm{MHz}, \mathrm{DMSO}_{6}\right.$, $\left.25^{\circ} \mathrm{C}\right): \delta 156.52,143.53,135.71,129.69,114.37,101.81$. ESI-MS $m / z[\mathrm{M}+\mathrm{H}]^{+}$: for $\mathrm{C}_{44} \mathrm{H}_{29} \mathrm{BrN}_{4} \mathrm{O}_{6}$ : calcd 789.13, found $\mathrm{m} / \mathrm{z}$ $789.12[\mathrm{M}+\mathrm{H}]^{+}$. UV-VIS $(\mathrm{MeOH}): \lambda_{\max }(\mathrm{nm}) ; 418,512,547$, $585,638$.

Porphyrin 1. To a solution of P1-OH (370 mg, $0.46 \mathrm{mmol})$ in $30 \mathrm{~mL}$ anhydrous $\mathrm{DMF}$, were added $\mathrm{K}_{2} \mathrm{CO}_{3}(1.29 \mathrm{~g}$, $9.38 \mathrm{mmol})$, KI (0.15 g, $0.93 \mathrm{mmol})$ and tri(ethylene glycol) monotosylate $(1.14 \mathrm{~g}, 3.75 \mathrm{mmol})$ and refluxed at $80{ }^{\circ} \mathrm{C}$ for $12 \mathrm{~h}$. Thereafter, the reaction mixture was cooled to room temperature and the solvent was removed under reduced pressure to give gummy purple residues. The resulting mixture was washed with chloroform and filtered under suction. The product was further purified by column chromatography using the $\mathrm{CHCl}_{3} / \mathrm{MeOH}(9: 1)$ system as the eluent to obtain purple gum (0.60 g, 84\%). ${ }^{1} \mathrm{H}$ NMR (400 $\left.\mathrm{MHz}, \mathrm{CDCl}_{3}, 25{ }^{\circ} \mathrm{C}\right)$ : 
$\delta$ 8.81-8.99 (m, 4H, bromophenyl-H), 7.91-8.19 (m, 6H, O-phenyl-H), 7.42 (s, 3H, p-phenyl-H), 6.95 (s, 3H, p-phenyl-H), 3.03-4.32 (m, 72H, TEG- $\left.\mathrm{CH}_{2}\right),-2.90$ (s, 2H, pyrrole, $\mathrm{NH}$ ). ${ }^{13} \mathrm{C}$ NMR (100 $\left.\mathrm{MHz}, \mathrm{CDCl}_{3}, 25{ }^{\circ} \mathrm{C}\right): \delta 157.95,143.79,135.85$, 129.95, 114.81, 72.18, 69.86, 67.76, 61.18, 29.70.

ESI-MS $\mathrm{m} / \mathrm{z}$ for $\mathrm{C}_{80} \mathrm{H}_{101} \mathrm{BrN}_{4} \mathrm{O}_{24}$, calcd: 1580.60; found $1581.60[\mathrm{M}+\mathrm{H}]^{+}$.

UV-VIS $\left(\mathrm{CHCl}_{3}\right): \lambda_{\max }(\mathrm{nm}) ; 421,512,547,585,638$.

Zinc insertion into 5-( $p$-bromophenyl)-10,15,20-tri( $m$-di- $O$ TEG phenyl)porphyrin. To a $50 \mathrm{~mL}$ two-neck round bottom flask containing $30 \mathrm{~mL}$ of the $\mathrm{CHCl}_{3} / \mathrm{MeOH}$ mixture $(\mathrm{v} / \mathrm{v}=9 / 1)$ Porphyrin 1 (600 mg, $0.380 \mathrm{mmol}$ ) was added and stirred for a while. Then, $\mathrm{Zn}(\mathrm{OAc})_{2}(300 \mathrm{mg}, 1.63 \mathrm{mmol})$ was added to the reaction mixture and refluxed at $65-70{ }^{\circ} \mathrm{C}$ for $2 \mathrm{~h}$. Thereafter, the reaction mixture was cooled to room temperature and filtered by suction to remove inorganic salts. The filtrate was evaporated and passed through a small pad of silica gel using the DCM/MeOH $(1: 1)$ system as the eluent. The product was evaporated under reduced pressure to yield a purple-red gum (580 mg, 86\%). ${ }^{1} \mathrm{H}$ NMR (400 MHz, $\mathrm{CDCl}_{3}, 25{ }^{\circ} \mathrm{C}$ ): $\delta$ 8.87-9.05 (m, 4H, bromophenyl-H), 7.89-8.03 (m, 6H, O-phenyl- $\mathrm{H})$, 7.45 (s, 3H, p-phenyl-H), 6.90 (s, 3H, p-phenyl-H), 3.05-4.33 (m, 72H, TEG-CH$).{ }^{13} \mathrm{C}$ NMR (100 MHz, $\mathrm{CDCl}_{3}$, $\left.25{ }^{\circ} \mathrm{C}\right): \delta$ 157.95, 143.79, 135.85, 129.95, 114.81, 72.18, $69.86,67.76,61.18,29.70$. Elemental analysis: calcd for $\mathrm{C}_{80} \mathrm{H}_{99} \mathrm{BrN}_{4} \mathrm{O}_{24} \mathrm{Zn}$ : C 58.238, H 6.06, N 3.40. Found: C 57.29, $\mathrm{H}$ 6.38, $\mathrm{N}$ 2.93. ESI-MS $\underline{m} / z$ for $\mathrm{C}_{80} \mathrm{H}_{99} \mathrm{BrN}_{4} \mathrm{O}_{24} \mathrm{Zn}$, calcd 1644.54, found 1645.16 $[\mathrm{M}+\mathrm{H}]^{+}$. UV-VIS $\left(\mathrm{CHCl}_{3}\right): \lambda_{\max }(\mathrm{nm})$; 426, 557, 604 .

Porphyrin 2. The demethylation of $\mathbf{P} 2$ is similar to P1, 1 equivalent of 5,15-di( $p$-bromophenyl)-10,20-di(3,5-dimethoxyphenyl)porphyrin, 200 equivalents of $1 \mathrm{M} \mathrm{BBr}_{3}$ (in DCM) were stirred under argon at $-78{ }^{\circ} \mathrm{C}$ to $25{ }^{\circ} \mathrm{C}$ for $12 \mathrm{~h}$. $\mathbf{P 2}-\mathbf{O H}$ was obtained as a purple solid in $90 \%$ yield. ${ }^{1} \mathrm{H}$ NMR (400 MHz DMSO-d $\left.{ }_{6}, 25{ }^{\circ} \mathrm{C}\right): \delta 9.72(\mathrm{~s}, 4 \mathrm{H},-\mathrm{OH}), 8.85-8.98$ (m, 8H, bromophenyl-H), 8.03-8.17 (m, 4H, O-phenyl-H), 6.78-7.15 (m, 2H, p-phenyl-H), -3.05 (s, 2H, pyrrole, $\mathrm{NH}$ ); ${ }^{13} \mathrm{C}$ NMR (100 MHz, DMSO-d 6 ): $\delta$ 157.02, 143.13, 140.92, $136.48,130.43,122.50,120.95,118.72,114.78$; ESI-MS $\mathrm{m} / \mathrm{z}$ calcd for $\mathrm{C}_{44} \mathrm{H}_{28} \mathrm{Br}_{2} \mathrm{~N}_{4} \mathrm{O}_{4}[\mathrm{M}+\mathrm{H}]^{+}$, 835.0477; found, 835.1550.

To a solution of P2-OH (500 mg, $0.598 \mathrm{mmol})$ in $30 \mathrm{~mL}$ anhydrous DMF, were added $\mathrm{K}_{2} \mathrm{CO}_{3}(1.24 \mathrm{~g}, 9.00 \mathrm{mmol})$, KI (0.200 g, $1.20 \mathrm{mmol})$ and tri(ethylene glycol)monotosylate $(1.09 \mathrm{~g}, 3.60 \mathrm{mmol})$ and refluxed at $80^{\circ} \mathrm{C}$ for $12 \mathrm{~h}$. Thereafter, the reaction mixture was cooled to room temperature and the solvent was removed under reduced pressure to give gummy purple residues. The resulting mixture was washed with chloroform and filtered under suction. The product was further purified by passing through a pad of silica using chloroform as the eluent to obtain purple gum (645 mg, 79\%). ${ }^{1} \mathrm{H}$ NMR (400 MHz, $\mathrm{CDCl}_{3}, 25^{\circ} \mathrm{C}$ ): $\delta$ 8.87-9.05 (m, 8H, bromophenyl-H), 7.87-8.09 (m, 4H, O-phenyl-H), $7.46(\mathrm{~s}, 2 \mathrm{H}$, p-phenyl-H), 6.89 (s, 2H, p-phenyl-H), 2.88-4.27 (m, 48H, TEG- $\left.\mathrm{CH}_{2}\right)$. $-2.90(\mathrm{~s}, 2 \mathrm{H}$, pyrrole, $\mathrm{NH})$. ESI-MS $\mathrm{m} / \mathrm{z}$ calcd for $\mathrm{C}_{68} \mathrm{H}_{76} \mathrm{Br}_{2} \mathrm{~N}_{4} \mathrm{O}_{16}, 1364.36$; found 1366.16 [M $\left.+\mathrm{H}\right]^{+}$. UV-vis $\left(\mathrm{CHCl}_{3}\right): \lambda_{\max }(\mathrm{nm}) ; 421,512,547,585,638$.
Zn was inserted into Porphyrin 2 using the same procedure as Porphyrin 1 (578 mg, 92\%). ${ }^{1} \mathrm{H}$ NMR (400 $\mathrm{MHz}, \mathrm{CDCl}_{3}$, $\left.25{ }^{\circ} \mathrm{C}\right): \delta$ 8.87-9.05 (m, 8H, bromophenyl-H), 7.87-8.09 $(\mathrm{m}, 4 \mathrm{H}$, $O$-phenyl-H), 7.46 (s, 2H, p-phenyl-H), 6.89 (s, 2H, p-phenyl-H), 2.88-4.27 (m, 48H, TEG-CH $) .{ }^{13} \mathrm{C}-\mathrm{NMR}\left(100 \mathrm{MHz}, \mathrm{CDCl}_{3}\right.$, $\left.25{ }^{\circ} \mathrm{C}\right): \delta 165.71,152.92,145.22,144.89,139.97,7237.31$, 131.05, 127.05, 126.16, 124.10, 117.29, 115.97, 110.12, 96.84, 77.34, 72.59, 70.11, 67.05, 65.35, 63.04, 61.67, 56.12. Elemental analysis: calcd for $\mathrm{C}_{68} \mathrm{H}_{74} \mathrm{Br}_{2} \mathrm{~N}_{4} \mathrm{O}_{16} \mathrm{Zn}$ : C 57.17, $\mathrm{H}$ 5.22, N 3.92; found: C 57.24, H 5.42, N 3.28.

ESI-MS $m / z \quad[\mathrm{M}+\mathrm{H}]^{+}$: for $\mathrm{C}_{68} \mathrm{H}_{74} \mathrm{Br}_{2} \mathrm{~N}_{4} \mathrm{O}_{16} \mathrm{Zn}$ : calcd 1426.2738, found 1426.2842 $[\mathrm{M}+\mathrm{H}]^{+}$. UV-VIS $\left(\mathrm{CHCl}_{3}\right)$ : $\lambda_{\text {max }}(\mathrm{nm}) ; 426,557,604$.

$\mathbf{O T T}_{1} \mathbf{P}$. Thiophene diboronic ester (13 $\left.\mathrm{mg}, 0.051 \mathrm{mmol}\right)$ was placed in a two-necked round bottom flask, equipped with a condenser and degassed water: DMF 1:3 (15 mL) was added under nitrogen to dissolve the mixture in the flask and Porphyrin 1 (167 mg, $0.101 \mathrm{mmol}$ ) was added under nitrogen. The mixture was stirred under nitrogen while heating at around $50{ }^{\circ} \mathrm{C}$. Twenty minutes later, $\mathrm{K}_{2} \mathrm{CO}_{3}(140 \mathrm{mg}, 1.01 \mathrm{mmol})$ was dissolved in degassed water $(3 \mathrm{~mL})$ and added to the reaction flask. Finally $\mathrm{Pd}(\mathrm{OAc})_{2}\left(5.05 \times 10^{-3} \mathrm{mmol}\right)$ was added to the flask and the temperature was increased to $80^{\circ} \mathrm{C}$. The mixture was stirred under nitrogen while heating at $80^{\circ} \mathrm{C}$ for $48 \mathrm{~h}$. Solvents from the reaction mixture were removed under reduced pressure and the resulting solid residue was dissolved in chloroform and filtered under suction. The filtrate was further purified by column chromatography using the $\mathrm{CH}_{3} \mathrm{Cl} / \mathrm{MeOH}$ (1:1) system as the eluent. A solid purple product was obtained (100 mg, 61\%). ${ }^{1} \mathrm{H}$ NMR (400 $\mathrm{MHz} \mathrm{CDCl}_{3}, 25{ }^{\circ} \mathrm{C}$ ): $\delta$ 8.97-8.88 (m, pyrrolic-H), 8.22-7.75 (m, Ar-H), 7.50-6.95 (m, Ph-H), 4.33-3.15 (m, PEG-CH ( $_{2}$; ${ }^{13} \mathrm{C}$ NMR (100 MHz, $\left.\mathrm{CDCl}_{3}, 25^{\circ} \mathrm{C}\right): \delta 157.67,149.78,143.18,127.32,126.43,120.80$, 120.33, 114.85, 71.93, 71.92, 70.66, 70.16, 70.14, 69.85, 67.80, 61.05, 61.02; elem. anal. for $\mathrm{C}_{164} \mathrm{H}_{200} \mathrm{~N}_{8} \mathrm{O}_{48} \mathrm{SZn}_{2}$ : calcd C, 61.28; H, 6.27; N, 3.49; S, 1.00; found C, 61.85; H, 6.34; $\mathrm{N}, 3.20 \%$. ESI-MS $m / z$ calcd for $\mathrm{C}_{164} \mathrm{H}_{200} \mathrm{~N}_{8} \mathrm{O}_{48} \mathrm{SZn}_{2}[\mathrm{M}+\mathrm{H}]^{2+}$, 3209.1759; found, 1605.5490.

$\mathbf{O T T}_{2} \mathbf{P}$. Into a $25 \mathrm{~mL}$ two-necked round bottom flask Porphyrin 1 (0.530 g, $0.650 \mathrm{mmol}$ ) and 5,5'-bis(tributylstannyl)2,2'-bithiophene $(0.260 \mathrm{~g}, 0.350 \mathrm{mmol})$ were added. Anhydrous toluene/THF mixture $(2: 1,30 \mathrm{~mL})$ was added to the flask and the resulting solution was degassed using three freeze-pumpthaw cycles. The catalyst $\mathrm{Pd}\left(\mathrm{PPh}_{3}\right)_{4}(0.0175 \mathrm{mmol})$ was added to the reaction flask under an argon atmosphere. The temperature of the reaction was raised to $80-90{ }^{\circ} \mathrm{C}$ and stirred for $48 \mathrm{~h}$. The solvent of the reaction mixture was removed under reduced pressure to give a purple solid residue. The solid residue was further washed with cold $1 \mathrm{M}$ aqueous $\mathrm{NaOH}$ followed by diethyl ether $\left(\mathrm{Et}_{2} \mathrm{O}\right)$. The resulting product was dissolved in chloroform and passed through a pad of silica. The solvent was removed and dried under vacuum to obtain a purple residue (250 mg, 21\%). ${ }^{1} \mathrm{H}-\mathrm{NMR}$ (400 $\mathrm{MHz}, \mathrm{CDCl}_{3}$, $\left.25{ }^{\circ} \mathrm{C}\right): \quad \delta$ 8.71-8.49 (m, pyrrolic-H), 8.18-8.28 (m, Ar-H), 7.19-7.79 (m, Ph-H), 3.61-4.50 (m, TEG-CH $)$ ppm. ${ }^{13} \mathrm{C}-\mathrm{NMR}$ $\left(100 \mathrm{MHz}, \mathrm{CDCl}_{3}, 25{ }^{\circ} \mathrm{C}\right): \delta$ 159.21, 146.07, 141.64, 128.28, 
118.50, 103.73, 72.59, 2.59, 70.98, 70.45, 69.83, 68.26, 61.71, $61.68 \mathrm{ppm}$. ESI-MS $\mathrm{m} / \mathrm{z}$ Calcd for $\mathrm{C}_{168} \mathrm{H}_{202} \mathrm{~N}_{8} \mathrm{O}_{48} \mathrm{~S}_{2} \mathrm{Zn}_{2}$ $[\mathrm{M}+2 \mathrm{H}]^{+2}, 3291.1636$; found, 1645.5221. Elemental analysis for $\mathrm{C}_{168} \mathrm{H}_{202} \mathrm{~N}_{8} \mathrm{O}_{48} \mathrm{~S}_{2} \mathrm{Zn}_{2}$ calcd: C, 61.21; $\mathrm{H}, 6.18 ; \mathrm{N}, 3.40$; S, 1.95. Found: C, 61.81; H, 6.57; N, 3.11.

PTTP. Into a $50 \mathrm{ml}$ two-necked round bottom flask Porphyrin 2 (350 mg, $0.245 \mathrm{mmol}$ ) and 5,5'-bis(tributylstannyl)2,2'-bithiophene (180 mg, $245 \mathrm{mmol}$ ) were added and dissolved in anhydrous toluene: DMF mixture $(2: 1, \mathrm{v} / \mathrm{v}, 30 \mathrm{~mL})$ and then degassed through three freeze-pump-thaw cycles. After stirring for $15 \mathrm{~min}$, the catalyst $\operatorname{Pd}\left(\mathrm{PPh}_{3}\right)_{4}(12.2 \mathrm{mmol})$ was added and the resulting reaction mixture was refluxed under argon at $90{ }^{\circ} \mathrm{C}$ for $48 \mathrm{~h}$. After the reaction was complete, the mixture was cooled down and precipitated in cold $\mathrm{MeOH}$. The precipitates were collected by filtration and washed with $\mathrm{MeOH}$ (3-4 times) followed by $n$-hexane. The precipitates were redissolved in chloroform and precipitated in cold methanol. The polymer was obtained as a purple solid (57\% yield). ${ }^{1} \mathrm{H}-\mathrm{NMR}\left(400 \mathrm{MHz}, \mathrm{CDCl}_{3}, 25{ }^{\circ} \mathrm{C}\right): \delta 9.05-8.95(\mathrm{~m}$, pyrrolic-H), 7.75-8.02 (m, Ar-H), 7.56-6.85 (m, Ph-H), 4.35-2.10 (m, TEG$\left.\mathrm{CH}_{2}\right) .{ }^{13} \mathrm{C}-\mathrm{NMR}\left(100 \mathrm{MHz}, \mathrm{CDCl}_{3}, 25{ }^{\circ} \mathrm{C}\right): \delta$ 158.67, 150.03, 144.03 , 135.77, 135.03, 132.13, 131.66, 130.90, 129.71, 128.83, 125.60, 124.78, 124.59, 124.23, 123.64, 113.86, 69.37, 55.55, 53.55. $M_{\mathrm{n}}=3109, M_{\mathrm{w}} / M_{\mathrm{n}}=1.21$; UV-vis $\left(\mathrm{CHCl}_{3}\right): \lambda_{\max }(\mathrm{nm})$; $431,557,604$.

\section{Acknowledgements}

We acknowledge TÜBİTAK for financial support (project no: TBAG 112T058). We thank Dr J.A. Kitchen, University of Southampton, for determining the crystal structures of porphyrins $\mathbf{P} 2$ and $\mathbf{P 5}$.

\section{References}

1 J. P. Celli, B. Q. Spring, I. Rizvi, C. L. Evans, K. S. Samkoe, S. Verma, B. W. Pogue and T. Hasan, Chem. Rev., 2010, 110, 2795-2838.

2 M. Ethirajan, Y. Chen, P. Joshi and R. K. Pandey, Chem. Soc. Rev., 2011, 40, 340-362.

3 T. Maisch, J. Baier, B. Franz, M. Maier, M. Landthaler, R.-M. Szeimies and W. Baumler, Proc. Natl. Acad. Sci. U. S. A., 2007, 104, 17, 7223-7228.

4 T. Ishi-I, Y. Taguri, S.-H. Kato, M. Shigeiwa, H. Gorohmaru, S. Maedad and S. Mataka, J. Mater. Chem., 2007, 17, 33413346.

5 F. Hammerer, G. Garcia, S. Chen, F. Poyer, S. Achelle, C. Fiorini-Debuisschert, M.-P. Teulade-Fichou and P. Maillard, J. Org. Chem., 2014, 79, 1406-1417.
6 M. Drobizhev, Y. Stepanenko, Y. Dzenis, A. Karotki, A. Rebane, P. N. Taylor and H. L. Anderson, J. Am. Chem. Soc., 2004, 126, 15352-15353.

7 M. Drobizhev, Y. Stepanenko, Y. Dzenis, A. Karotki, A. Rebane, P. N. Taylor and H. L. Anderson, J. Phys. Chem. $B, 2005$, 109, 7223-7236.

8 A. Nowak-Krol, M. Grzybowski, J. Romiszewski, M. Drobizhev, G. Wicks, M. Chotkowski, A. Rebane, E. Gorecka and D. T. Gryko, Chem. Commun., 2013, 49, 8368-8370.

9 M. C. DeRosa and R. J. Crutchley, Coord. Chem. Rev., 2002, 233-234, 351-371.

10 B. W. Henderson and T. J. Dougherty, Photochem. Photobiol., 1992, 55, 145-147.

11 D. E. Dolmans, D. Fukumura and R. K. Jain, Nat. Rev. Cancer, 2003, 3, 380-387.

12 S. G. Awuah and Y. You, RSC Adv., 2012, 2, 1116911183.

13 N. Adarsh, R. R. Avirah and D. Ramaiah, Org. Lett., 2010, 12, 5720-5723.

14 S. G. Awuah, J. Polreis, V. Biradar and Y. You, Org. Lett., 2011, 13, 3884-3887.

15 R. L. Watley, S. G. Awuah, M. Bio, R. Cantu, H. B. Gobeze, V. N. Nesterov, S. K. Das, F. D’Souza and Y. You, Chem. Asian J., 2015, 10, 1335-1343.

16 S. Ji, J. Ge, D. Escudero, Z. Wang, J. Zhao and D. Jacquemin, J. Org. Chem., 2015, 80, 5958-5963.

17 N. Xiang, Y. Liu, W. Zhou, H. Huang, X. Guo, Z. Tan, B. Zhao, P. Shen and S. Tan, Eur. Polym. J., 2010, 46, 10841092.

18 Y. Liu, N. Xiang, X. Feng, P. Shen, W. Zhou, C. Weng, B. Zhao and S. Tan, Chem. Commun., 2009, 24992501.

19 H. Maeda, J. Controlled Release, 2012, 164, 138-144.

20 J. S. Lindsey, Acc. Chem. Res., 2010, 43, 300-311.

21 P. D. Rao, S. Dhanalekshmi, B. J. Littler and J. S. Lindsey, J. Org. Chem., 2000, 65, 7323-7344.

22 J. K. Laha, S. Dhanalekshmi, M. Taniguchi, A. Ambroise and J. S. Lindsey, Org. Process Res. Dev., 2003, 7, 799-812.

23 S. J. Narayanan, B. Sridevi, A. Srinivasan, T. K. Chandrashekar and R. Roy, Tetrahedron Lett., 1998, 39, 7389-7392.

24 B. J. Littler, Y. Ciringh and J. S. Lindsey, J. Org. Chem., 1999, 64, 2864-2872.

25 G. R. Geier, B. J. Littler and J. S. Lindsey, J. Chem. Soc., Perkin Trans. 2, 2001, 701-711.

26 L. Wen, M. Li and J. B. Schlenoff, J. Am. Chem. Soc., 1997, 119, 7726-7733.

27 W. Li, L. Li, H. Xiao, R. Qi, Y. Huang, Z. Xie, X. Jing and H. Zhang, RSC Adv., 2013, 3, 13417-13421.

28 R. W. Redmond and J. N. Gamlin, Photochem. Photobiol., 1999, 70, 391-475. 